DOI: 10.15740/HAS/IJAS/17.2/328-334

\title{
Assessment of productivity of pangas catfish (Pangasius pangasius, Hamilton-1822) culture in jute retting pond in Murshidabad district
}

\author{
Samiran Patra* and Uttam Roy \\ Murshidabad Krishi Vigyan Kendra (West Bengal University of Animal and Fishery Sciences), \\ Murshidabad (W.B.) India (Email: samiangelindia@gmail.com)
}

\begin{abstract}
Murshidabad district is the highest jute producer district in West Bengal where maximum numbers of ponds beels, canals and irrigational channels are being used for jute retting from July to September and after retting, water bodies remain uncultured. But few farmer's, they were culture traditionally with IMC and exotic carps and getting very low yield (3.66q ha $\left.{ }^{-1} \mathrm{yr}^{-1}\right)$. In that condition Murshidabad KVK has designed one OFT trails having three treatments, Farmer's Practice (FP), Technology Option-I (TO-I) and Technology Option-II (TO-II) on air-breathing fish pangas (Pangasius pangasius) and conducted in farmers'

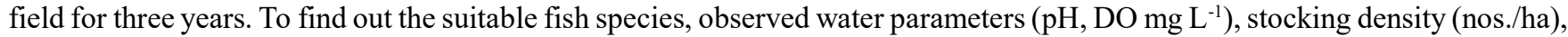
length $(\mathrm{cm})$, weight $(\mathrm{g})$, survival rate $(\%)$, yield $\left(\mathrm{q} \mathrm{ha}^{-1} \mathrm{yr}^{-1}\right)$, cost of culture $\left(\mathrm{Rs} . \mathrm{ha}^{-1} \mathrm{yr}^{-1}\right)$ gross return $\left(\mathrm{Rs}^{-1} \mathrm{ha}^{-1} \mathrm{yr}^{-1}\right)$, net return (Rs. $\left.\mathrm{ha}^{-1} \mathrm{yr}^{-1}\right), \mathrm{BC}$ ratio and disease incidence etc. The effect of water $\mathrm{pH}$ and $\mathrm{DO}\left(\mathrm{mg} \mathrm{L}^{-1}\right)$ in post jute retting pond and fish stocking pond indicate, there were a statistically significant difference between three treatments at $(p<.05)$. Stocking density in three treatments were 15000 nos. ha ${ }^{-1}$ (IMC and exotic carps), 11250 nos. ha ${ }^{-1}$ and 15000 nos. ha $^{-1}$ (pangas, size 2.5"). In this trial it was observed that the mean (SD) initial length $(\mathrm{cm})$, initial weight $(\mathrm{g})$ and final length $(\mathrm{cm})$ were not statistically significant at $p>.05$ but in case of final weight $(\mathrm{g})$ and weight gain $(\mathrm{g})$ there were statistically significant at $\mathrm{p}<.05$. The survival rate $(\%)$ was lowest in FP (35.04 \pm 4.51$)$ and highest in TO-I (67.55 \pm 17.50$)$ and not statistically significant $(p>.05)$. The mean (SD) yield (q ha $\left.{ }^{-1} \mathrm{yr}^{-1}\right)$ was high statistically significant difference found among three treatments $(p \leq 001)$. The average net profits were Rs.65680.0, Rs. 223841.0 and Rs. $337551.0 \mathrm{ha}^{-1} \mathrm{yr}^{-1}$. in FP, TO-I and TO-II, respectively. The highest mean B:C ratio was 2.44 in TO-II. With the all concerned it was observed TO-II gives the best result among these three treatments in these three years trials.
\end{abstract}

Key Words : Pangas fish, Jute retting pond, Water quality, Feeding habit, Yield

View Point Article : Patra, Samiran and Roy, Uttam (2021). Assessment of productivity of pangas catfish (Pangasius pangasius, Hamilton1822) culture in jute retting pond in Murshidabad district. Internat. J. agric. Sci., 17 (2) : 328-334, DOI:10.15740/HAS/IJAS/17.2/328-334. Copyright@2021: Hind Agri-Horticultural Society.

Article History : Received : 25.02.2021; Revised : 27.02.2021; Accepted : 16.03.2021

\footnotetext{
* Author for correspondence :
} 